\title{
Failure of Ethical Compliance: The Case of Volkswagen
}

\author{
Kashfia Ameen \\ Lecturer, Department of General Management, Independent University, Bangladesh (IUB) \\ Plot 16, Aftabuddin Ahmed Road, Bashundhara, Dhaka 1229, Bangladesh
}

\begin{abstract}
Violation of business ethics due to environmental mitigation pressures is frequently observed in the automobile industry. Accordingly, this case analyzes the ethical implications of the 2015 Volkswagen emissions scandal in the United States (U.S.). The review of Volkswagen is fitting purely because of the extent and notoriety of the controversy. The case established business ethics in global agenda and public consciousness, having serious implications on how major corporations are run. Volkswagen faces two allegations: air pollution and cheating on emissions tests. This case focuses on the corporate fraud in the American market. Kantian ethics and Utilitarianism will be used to argue that Volkswagen's rigging of emissions tests was unethical behaviour on a massive scale. The assumptions and limitations of the theories are explored, followed by a discussion and conclusion.
\end{abstract}

Keywords - business ethics, corporate social responsibility, ethical compliance, Kantian ethics, Utilitarianism

\section{INTRODUCTION}

The 1990s saw an accelerated development of formal business ethics in response to the emergence of multinational corporations with limited social responsibility (Jones, Parker \& Bos, 2005). 'Business ethics is rules, standards, codes, or principles which provide guidelines for morally right behaviour and truthfulness in specific business situations' (Lewis, 1985, p. 381). Crane and Matten (2016, p. 5) describe industry principles as 'a study of industry situation, behavior, and decision where issues of correct and incorrect are addressed'. Although common definitions emphasize the rightness or wrongness of behaviour, scholars disagree on what is ethical or unethical (Lewis, 1985). Consequently, there is an absence of a generally recognized, specific definition of business ethics in literature (Sparks \& Pan, 2009).

Volkswagen faces two allegations: air pollution and cheating on emissions tests (O'Dwyer, 2016). This paper focuses on the corporate fraud in the American market (Li et al., 2018). Kantian ethics and Utilitarianism will be used to argue that Volkswagen's rigging of emissions tests was unethical behaviour on a massive scale (Warford, 2016). The assumptions and limitations of the theories are explored, followed by a discussion and conclusion.

\section{Case Summary}

The Volkswagen case highlights the failures of ethical compliance (Warford, 2016). The ethics scandal is about Volkswagen engineers altering engine operations to meet U.S. emissions testing standards (Rogerson, 2017). Volkswagen used 'defeat devices' which ensured that emissions control would only be activated during regulatory tests (Trope \& Ressler, 2016). Under normal driving conditions, exhaust emissions were forty times higher than the legal limit (VanSandt, 2016). This cheating continued for ten years until detected (Shepardson, 2017). The scandal started when Volkswagen was issued a notice by the U.S. Environmental Protection Agency (EPA) in 2015 for violating the Clean Air Act (Shepardson, 2017). The investigation found that 482,000 cars were using defeat devices (Plungis, 2016).

Volkswagen initially lied to the EPA and cited 'technical problems' (Stoklosa, 2016). Eventually, Volkswagen pleaded guilty in 2017 and settled to a $\$ 4.3$ billion agreement, the highest ever criminal fine imposed on a carmaker in America (Shepardson, 2017). Subsequently, Volkswagen issued a public apology and arranged to pay $\$ 22$ billion to claimants including car owners, dealers and regulators (Hotten, 2015). Volkswagen lost more than one-third of its stock value, 500,000 cars were recalled, sales were stopped, six executives were charged and the chief executive officer for North America and other directors resigned (Singer, 2015). Volkswagen's actions are legal under European Union emissions regulations and only American customers are being compensated (O’Dwyer, 2016). 
Volkswagen's U.S. boss knew about the misconduct since early 2014, engineers rigged the tests due to pressure from management and executives kept all stakeholders in the dark (Rogerson, 2017; Zhou, 2016). Aggressive goals for the U.S. market, technical loopholes, fraudulent marketing, unethical governance and management's justification of ethical violations have led to the cheating (Lynch, 2016). The ethics failure can be traced to Volkswagen's organizational culture, underlining the importance of proper board and management structure (Elson, Ferrere \& Goossen, 2015). However, it is beyond the scope of this paper to justify that made the decision; the fact is that an unethical choice was made (VanSandt, 2016).

The Volkswagen emissions scandal represents the antithesis of ethical business conduct, having negative repercussions for both direct and indirect stakeholders (Mansouri, 2016). The case is cautionary because the legendary German automaker was considered a globally dependable brand, having self-proclaimed to be ethical and ecological (Adams, 2015). Human resource policies, codes and employee training were questioned as the world was shocked by Volkswagen's brazen disregard for business ethics and environmental regulations (Halfond, 2016). Consequently, Volkswagen's ambitions of becoming the world's leading car manufacturer came crashing with its decades of reputation (Singer, 2015). Compliance-based ethics and regulations often have the reverse outcome (Mansouri, 2016). Accordingly, many authors propose a reformulation of U.S. emissions standards to coordinate with automakers (Mansouri, 2016).

\section{LITERATURE REVIEW}

This section of the paper will examine Kantian ethics and Utilitarianism to discuss the ethical issues raised by the case.

Kant is careful the most important creator of deontology and his 'firmly very important and universalistic divinity prescribe a rather fixed, positivistic duty based saying that guide the actualization of altruism' (Teck, How, Karuppiah \& Ho, 2018, p. 13). The Kantian categorical imperative is a fundamental moral law which maintains that actions should be based on personal rules or maxims (Marques, 2015; Yang, 2006). One should only act according to the maxim that he is willing for everyone else to follow in the same situation (Weiss, 2009). Hence, 'a maxim should only be considered permissible if it could become a universal law' (Marques, 2015, p. 3). Unlike Utilitarianism, Kant's categorical imperative places the moral authority for an action on duty towards others and humanity (Weiss, 2009). Kantianism further holds that 'people should be treated as ends and never purely as means to the ends of others' (Weiss, 2009, p. 107). Kant believes that in an ethical dilemma, everyone involved should be treated with respect, fairness and honesty (Sandel, 2010).

However, Kantianism is criticized for being irrelevant and imprecise as application of universal moral rules is unfeasible (Milkoreit, 2015). Kant does not clarify how to prioritize duties and business decisions cannot consider all humanity (Weiss, 2009). When individuals are treated equally, differences in stakeholder power and other elements in an ethical dilemma are ignored, making it difficult to resolve conflict of interest (Valentinov, 2017). Additionally, no deontological principle can satisfy all of Kant's strict assumptions (Yang, 2006). Nonetheless, Kantian ethics forces businesses to be dutiful and accountable as human welfare is considered in decision making (Weiss, 2009). Therefore, Kantianism is a useful theory to understand business ethics and universal policies (Marques, 2015).

Conversely, Utilitarianism is a more contemporary, relative approach proposing that an 'action is ethical if it produces the greatest wellbeing for the greatest number' (Weiss, 2009, p. 104). Bentham and Mill, the founders of Utilitarianism, claim that the 'function of morality is to develop human welfare by maximizing benefits and minimizing harms' (Beauchamp \& Bowie, 2004, p. 17). Utilitarians assert that the 'moral worth of actions is determined by their consequences' (Beauchamp \& Bowie, 2004, p. 17). Utilitarianism thus measures the 'validity and morality of an act wholly dependent on the consequences as opposed to the circumstances or the intrinsic nature of the act or anything that happens before the act' (Teck et al., 2018, p. 15).

Mills proposes two foundations of Utilitarianism (Beauchamp \& Bowie, 2004). The normative foundation concludes that actions should promote happiness and reduce pain (Shaw, Barry, Issa \& Catley, 2013). Alternatively, the psychological foundation says that 'human sympathies should benefit everyone while controlling unsympathetic attitudes that harm others' (Beauchamp \& Bowie, 2004, p. 17).

Utilitarian philosophies are further classified into two types: Act and Rule Utilitarianism (Weiss, 2009). Act Utilitarians concur that moral rules can be broken if it leads to the greatest good for the greatest number in a 
particular situation (Beauchamp \& Bowie, 2004). Conversely, Rule Utilitarianism contends that rules are significant, unchangeable and must be used to decide whether an act will produce the greatest benefit (Weiss, 2009).

However, Utilitarians fail to specify how pleasure should be measured and disagree on what constitutes as good (Hodder, 1892; Shaw, 1999). Hedonistic Utilitarians say that any act that maximizes pleasure is right while Pluralist Utilitarians believe in a range of intrinsic values that maximize pleasure (Beauchamp \& Bowie, 2004; Ewing, 1948). Act and Rule Utilitarians also lack consensus regarding the importance of obeying rules (Beauchamp \& Bowie, 2004). There is no definitive guide to determine how to treat everyone equally and which action will provide the greatest benefit to the greatest number (Maclean, 1993). Moreover, Utilitarianism ignores non-utilitarian factors and does not consider the role of justice and rights in decision making (Beauchamp \& Bowie, 2004).

Nevertheless, Utilitarianism is useful in conducting stakeholder analysis as it forces businesses to consider collective interest and formulate alternate strategies to maximize benefits for all parties involved (Weiss, 2009). Additionally, Utilitarianism can be a framework for flexible and innovative problem solving because it recognizes that there is no intrinsic right or wrong as long as the outcome is pleasurable (Teck et al., 2018). Current corporate tools such as goal setting, cost-benefit analysis and risk assessment show influences of Utilitarianism (Beauchamp \& Bowie, 2004).

\section{Case Analysis}

Application of Kantian ethics and Utilitarianism to the Volkswagen ethics scandal involves several stakeholders (Trump \& Newman, 2017). For the purpose of this paper, these include employees, management, shareholders, customers, regulators and the American public (Caria \& Hermans, 2016).

The Kantian view on the Volkswagen case will now be discussed (Caria \& Hermans, 2016). Kantian approaches are useful when major corporations breach the minimum content of universal moral values leading to major social, political and legal repercussions that force companies to observe absolute ethical standards (Teck et al., 2018).

The ethics failure highlights Volkswagen's lack of core moral values (Teck et al., 2018). Kantian ethics argue that motives for actions are of utmost importance and should involve a sense of duty (Beauchamp \& Bowie, 2004). Kantianism protects employee value and focuses on 'the moral action itself', the choice Volkswagen had (Caria \& Hermans, 2016, p. 3). Volkswagen made choices that were immoral and illegal. Fraudulent advertising and claims disrespected potential customers by manipulating their selection (Beauchamp \& Bowie, 2004). Similarly, employees were treated as 'means to the ends of others' (Beauchamp \& Bowie, 2004, p. 22). Engineers were not allowed to work as rational, independent agents, their concerns were ignored and they had no freedom to act on their judgment (Beauchamp \& Bowie, 2004). Hence, Volkswagen violated Kantian duty and respect by treating customers and employees like money-making commodities (Weiss, 2009).

Kant's principles of morality and duty provide a rational framework for corporate action independent of personal goals (Schumann, 2001). Kant forbids purely profit based motives and states that the right decisions should be made for the right reasons (Beauchamp \& Bowie, 2004). Volkswagen was clearly opposed to this proposition, being motivated by self-interest and not goodwill (Beauchamp \& Bowie, 2004). Volkswagen's motivation did not stem from moral law; its main goal was 'expansion of corporate sovereignty' (Rhodes, 2016, p. 1501). According to Kant, this is a prudential but not a moral act (Beauchamp \& Bowie, 2004). Volkswagen thus failed its moral agency by ignoring basic business ethics (Orts \& Smith, 2017).

Kant proposes that the categorical imperative should be obeyed to act ethically (Weiss, 2009). The categorical imperative upholds the rights and interests of all stakeholders (Teck et al., 2018). Kant's imperative maxims were breached by Volkswagen as it engaged in lying and fraud (Beauchamp \& Bowie, 2004). Volkswagen did not make 'deontological decisions' by deceiving customers and regulators (Korner \& Volk, 2014, p. 139). Therefore, Volkswagen did not embrace Kant's categorically imperative moral values as it failed to protect employees and other stakeholders (Yang, 2006). 
Kantianism further illustrates that universal participation in certain actions is self-defeating and contradictory (Beauchamp \& Bowie, 2004). If Volkswagen's unethical behaviour is universalized, all other automakers would follow (Caria \& Hermans, 2016). Hence, Volkswagen's actions are not permissible (Caria \& Hermans, 2016).

Controversially, Teck et al. (2018) suggest that Volkswagen has transitioned to Kantianism post the scandal. Volkswagen has apologized, shown remorse and adopted a solid framework of rules and duty (Teck et al., 2018). Volkswagen's promise to regain the trust of all stakeholders shows a goodwill approach and may signify commitment to more categorically imperative standards (Orts \& Smith, 2017). However, there is no evidence to support these claims and it is questionable whether Volkswagen can create unbiased, universal moral codes based on Kantian ethics (Teck et al., 2018). Critics contend that Volkswagen is only trying to re-establish its corporate image through positive publicity (Teck et al., 2018).

Additionally, Kantianism is criticized for being inadequate as it fails to elaborate on human emotions, virtue and moral characteristics (Beauchamp \& Bowie, 2004; Solomon, 1992). Kant does not justify the ethical obligations of managers toward customers and employees (Beauchamp \& Bowie, 2004). Furthermore, Kantianism can influence managers to adopt rigid and authoritarian approaches (Pachterbeke, Freyer \& Saroglou, 2011).

Utilitarianism is a more straightforward and flexible approach to evaluate Volkswagen's ethical decisions (Teck et al., 2018). Although Utilitarianism is criticized for its lack of objectivity, 'firms are naturally expected to exert a utility value when they make corporate policies and decisions' (Teck et al., 2018, p. 15). Accordingly, Utilitarianism remains a central theory of business ethics to understand profit driven corporate goals (Shaw, 1999). Based on Utilitarianism, whether Volkswagen's actions are good or bad depend on its consequences (Marques, 2015). Volkswagen's sole goal was to maximize shareholder value with no regard for ethical implications (Bansal et al., 2015). This contradicts Utilitarianism, as Volkswagen did not consider producing the greatest good for the greatest number of people (Sandel, 2010). All the stakeholders have been adversely affected in different ways ranging from lost jobs, pay cuts, stock devaluation, sales drop, damaged corporate reputation and environmental pollution (Robinson, 2016). Hence, Volkswagen's actions directly oppose Utilitarian views (Teck et al., 2018). The one good thing that may have emerged from this scandal is the awareness it created about corporate fraud (Robinson, 2016).

Utilitarians concur that efficiency is not about increasing profit, but about maximizing human good (Beauchamp \& Bowie, 2004). Businesses should thus produce the maximum positive value or minimum disvalue for all stakeholders (Teck et al., 2018). Volkswagen's main aim was only to sell more cars. It did not show a Utilitarian judgment about the costs and benefits of its actions (Teck et al., 2018). Volkswagen failed to balance risks and benefits, in the process harming all stakeholders involved (Beauchamp \& Bowie, 2004). Therefore, Volkswagen's corporate and ethical policies were not balanced within Utilitarian theory (Beauchamp \& Bowie, 2004).

Based on Act Utilitarianism, Volkswagen's actions are unacceptable as the greater good was not maximized (Maclean, 1993). Although the fraud created short-term utility for Volkswagen, it did not lead to greater overall good (Caria \& Hermans, 2016). Everyone was worse off once the cheating was detected. Act Utilitarianism seeks punishment if it leads to greater utility (Caria \& Hermans, 2016). As an offender, Volkswagen deserves to be punished and civil and criminal lawsuits have been filed against the company (Hotten, 2015). This will discourage Volkswagen and other automakers from engaging in future ethical violations (Mansouri, 2016).

Volkswagen also violated Rule Utilitarianism by failing to comply with emissions regulations (Weiss, 2009). Rules were not central to Volkswagen's morality and its disregard for EPA standards did not maximize utility (Caria \& Hermans, 2016). Hence, Volkswagen's actions are not justified according to both Act and Rule Utilitarianism (Teck et al., 2018).

Evaluation of the case using Kantian ethics and Utilitarianism concludes that Volkswagen is guilty of gross ethical misconduct (Teck et al., 2018). A Kantian perspective would have forced Volkswagen to maintain a minimum moral conduct (Teck et al., 2018). Perhaps Volkswagen should have adopted a Utilitarian approach with relative adaptability (Teck et al., 2018). However, Kantianism and Utilitarianism are rule oriented and ignore individual interests (Valentinov, 2017). Both theories lack consistency and fail to converge on the right method to tackling ethical dilemmas (Gillon, 1985). Moreover, interpretations of morality are relative and subject to change (Shaw, 1999). Scholars thus disagree on which theory is more successful to illustrate ethical 
issues (Beauchamp \& Bowie, 2004). Therefore, further studies should examine the validity of the theories in producing ethical corporate judgments (Sparks \& Pan, 2009).

Ethics and moral courage should prevail at all organizational levels (Halfond, 2016). However, globalization and emerging state laws have left corporations unable to strictly adhere to a single, universal ethical approach (Teck et al., 2018). Hence, international brands need flexibility in ethical conduct to relate to different cultural and moral contexts (Teck et al., 2018). Furthermore, ethical concerns are easily ignored because moral principles and regulations are hard to measure and manage (Solomon, 1992). Consequently, corporate fraud remains a deep, systematic problem (Patel, 2015). Thus, ethical standards cannot be left to corporations or regulators alone and business ethics should to be overhauled with stringent consequences (Crane \& Matten, 2016).

\section{CONCLusion}

This paper provides a brief analysis of ethical issues to make a compelling argument against the 2015 Volkswagen emissions scandal. The case demonstrates that Volkswagen did not engage in Kantian or Utilitarian ethics by failing its moral responsibility (Orts \& Smith, 2017). Based on Kantianism, Volkswagen's actions are morally impermissible (Caria \& Hermans, 2016). On the other hand, Utilitarian approaches do not justify Volkswagen's cheating as no pleasure or goodness was maximized (Scarre, 1996). Accordingly, using Kantian ethics and Utilitarianism, it is argued that Volkswagen's corporate fraud was a huge ethical violation (Caria \& Hermans, 2016).

However, the theories are not without limitations in application (Schumann, 2001). Kantian universalistic assumptions and Utilitarian consequentialist propositions are criticized for being impractical in corporate scenarios (Beauchamp \& Bowie, 2004). Simultaneous profitability and ethical responsibility are not easy (Bansal et al., 2015). Managers need to balance and not overlook these trade-offs (Bansal et al., 2015). As companies are forced to adopt more comprehensive ethics, it is increasingly difficult to remain totally altruistic (Teck et al., 2018). Nonetheless, traditional distinction between the theories is useful in determining moral positions and managing the ethical transition of firms (Milkoreit, 2015). Kantian ethics and Utilitarianism thus remain valuable theories to evaluate ethical principles (Marques, 2015). Therefore, given their importance in understanding moral standards, future research should explore the relevance of the theories in modern business ethics (Teck et al., 2018).

\section{REFERENCES}

[1] Adams, C. 'VW scandal: ethics versus profit', retrieved 15 February, 2020 from https://economia.icaew.com/features/december2015/ethics-versus-profit.

[2] Bansal, T., King, M. \& Seijts, G. (2015). 'The Volkswagen emissions scandal: A case study in corporate misbehaviour', retrieved 15 March, 2018 from https://www.theglobeandmail.com/report-on-business/rob-commentary/the-vw-emissions-scandala-case-study-inwhat-not-to-do/article26550100/.

[3] Beauchamp, T. L. \& Bowie, N. E. (2004). Ethical Theory and Business. Upper Saddle River: Pearson Education.

[4] Caria, P. C. \& Hermans, M. (2016). 'The Volkswagen case; morally permissible?' Retrieved 18 January, 2020 from https://www.researchgate.net/publication/292722292_\%27The_Volkswagen\%27_case_morally_permissible?enrichId=rgreqd63039ea0ba51ab345bfde624d4e7dfa-

XXX\&enrichSource=Y292ZXJQYWdlOzI5MjcyMjI5MjtBUzozMjQ3MTg5ODc1NDY2MjVAMTQ1NDQzMDQ0NzQyMw\%3D\% 3D\&el=1_x_2\&_esc=publicationCoverPdf.

[5] Crane, A. \& Matten, D. (2016). Business Ethics: Managing Corporate Citizenship and Sustainability in the Age of Globalization. Oxford: Oxford University Press.

[6] Elson, C. M., Ferrere, C. K. \& Goossen, N. (2015). 'The Bug at Volkswagen: Lessons in Co-Determination, Ownership, and Board Structure', Journal of Applied Corporate Finance, Vol. 27, No. 4, pp 36-43.

[7] Ewing, A. C. (1948). 'Utilitarianism', Ethics, Vol. 58, No. 2, pp 100-111.

[8] Gillon, R. (1985). 'Utilitarianism', British Medical Journal, Vol. 290, No. 6479, pp 1411-1413.

[9] Halfond, J. (2016). 'Speaking Ethics To Power - Lessons From Volkswagen', retrieved 15 March, 2019 from https://www.huffingtonpost.com/jay-halfond/speaking-ethics-to-power-_b_10880852.html.

[10] Hodder, A. L. (1892). 'Utilitarianism', The International Journal of Ethics, Vol. 3, No. 1, pp 90-112. 12 
[11] Hotten, R. (2015). 'Volkswagen: The scandal explained', retrieved 16 February, 2020 from http://www.bbc.co.uk/news/business34324772 .

[12] Jones, C., Parker, M. \& Bos, R. T. (2005). For Business Ethics: A Critical Approach. New York: Routledge.

[13] Korner, A. \& Volk, S. (2014). 'Concrete and abstract ways to deontology: Cognitive capacity moderates construal level effects on moral judgments’, Journal of Experimental Social Psychology, Vol. 55, No. 1, pp 139-145.

[14] Lewis, P. V. (1985). 'Defining 'business ethics': Like nailing jello to a wall', Journal of Business Ethics, Vol. 4, No. 5, pp $377-383$.

[15] Li, L., Mcmurray, A., Xue, J., Liu, Z. \& Sy, M. (2018). 'Industry-wide corporate fraud: The truth behind the Volkswagen scandal', Journal of Cleaner Production, Vol. 172, No. 1, pp 3167-3175.

[16] Lynch, L. J. (2016). 'Volkswagen's lax ethical and emissions standards', retrieved 16 March, 2019 from https://www.washingtonpost.com/business/volkswagens-lax-ethical-and-emissions-standards/2016/10/13/aab55684-8fc0-11e6-9c85ac42097b8cc0_story.html?utm_term=.c642a37e4501.

[17] Maclean, A. (1993). The Elimination of Morality: Reflections on Utilitarianism and Bioethics. London: Routledge.

[18] Mansouri, N. (2016). 'A Case Study of Volkswagen Unethical Practice in Diesel Emission Test', International Journal of Science and Engineering Applications, Vol. 5, No. 4, pp 211-216.

[19] Marques, J. (2015). 'Universalism and Utilitarianism: An Evaluation of Two Popular Moral Theories in Business Decision Making', The Journal of Values-Based Leadership, Vol. 8, No. 2, pp 1-11.

[20] Milkoreit, M. (2015). 'Hot deontology and cold consequentialism - an empirical exploration of ethical reasoning among climate change negotiators', Climatic Change, Vol. 130, No. 3, pp 397-409.

[21] O’Dwyer, K. (2016). 'Utilitarianism: a protection for Volkswagen's immoral, but legal, emissions cheat?' Retrieved 15 March, 2018 from http://www.corporateresponsibilitynetwork.com/wp-content/uploads/topics-corporate-responsibility-society/regents160128_utilitarianism.pdf.

[22] Orts, E. W. \& Smith, N. C. (2017). The Moral Responsibility of Firms. Oxford: Oxford University Press.

[23] Pachterbeke, M. V., Freyer, C. \& Saroglou, V. (2011). 'When authoritarianism meets religion: Sacrificing others in the name of abstract deontology', European Journal of Social Psychology, Vol. 41, No. 7, pp 898-903.

[24] Patel, P. (2015). 'Engineers, Ethics, and the VW Scandal', retrieved 14 March, 2018 from https://spectrum.ieee.org/cars-that-think/atwork/education/vw-scandal-shocking-but-not-surprising-ethicists-say.

[25] Plungis, J. (2015). 'Carmakers cheating on emissions almost as old as pollution tests', retrieved 13 March, 2018 from http://www.dailyherald.com/article/20150927/business/150929346/.

[26] Rhodes, C. (2016). 'Democratic Business Ethics: Volkswagen's Emissions Scandal and the Disruption of Corporate Sovereignty', Organization Studies, Vol. 37, No. 10, pp 1501-1518.

[27] Robinson, G. (2016). 'Volkswagen: Emissions Scandal Due To Fraudulent Software', retrieved 13 March, 2018 from http://businessethicscases.blogspot.co.uk/2016/11/volkswagen-emissions-scandal-due-to.html.

[28] Rogerson, S. (2017). 'Is professional practice at risk following the Volkswagen and Tesla revelations? Software engineering under scrutiny', ACM Computers \& Society, Vol. 47, No. 3, pp 25-38.

[29] Sandel, M. (2010). Justice: What's the Right Thing to Do? New York: Farrar, Straus and Giroux.

[30] Scarre, G. (1996). Utilitarianism. London: Routledge.

[31] Schumann, P. L. (2001). 'A moral principles framework for human resource management ethics', Human Resource Management Review, Vol. 11, No. 1, pp 93-111. 14

[32] Shaw, W. H. (1999). Contemporary Ethics: Taking Account of Utilitarianism. Massachusetts: Blackwell Publishers Inc.

[33] Shaw, W. H., Barry, V., Issa, T. \& Catley, B. (2013). Moral Issues in Business. South Melbourne: Victoria Cengage Learning Australia.

[34] Shepardson, D. (2017). 'U.S. indicts six as Volkswagen agrees to \$4.3 billion diesel settlement', retrieved 13 March, 2018 from https://uk.reuters.com/article/us-volkswagen-emissions-epa/u-s-indicts-six-as-volkswagen-agrees-to-4-3-billion-diesel-settlementidUKKBN14V1T0.

[35] Singer, P. (2015). 'After VW: Ethical business and the question of honesty', retrieved 13 March, 2018 from https://www.theglobeandmail.com/globe-debate/after-vw-ethical-business-and-the-question-of-honesty/article26760335/. 
[36] Solomon, R. C. (1992). 'Corporate Roles, Personal Virtues: An Aristotelean Approach to Business Ethics', Business Ethics Quarterly, Vol. 2, No. 3, pp 317-339.

[37] Sparks, J. R. \& Pan, Y. (2009). 'Ethical Judgments in Business Ethics Research: Definition, and Research Agenda', Journal of Business Ethics, Vol. 91, No. 3, pp 405-418.

[38] Stoklosa, A. (2016). 'VW CEO Characterizes Diesel Scandal as a "Technical Problem," Says Company Didn't Lie', retrieved 13 March, 2018 from https://blog.caranddriver.com/vw-ceo-characterizes-diesel-scandal-as-a-technical-problem-says-company-didnt-lie/.

[39] Teck, T. S., How, L. C., Karuppiah, N. \& Ho, C. J. (2018). 'Universalism and Utilitarianism, Two Worlds Apart or Inextricably Linked?' Journal of Management and Sustainability, Vol. 8, No. 1, pp 13-19.

[40] Trope, R. L. \& Ressler, E. K. (2016). 'Mettle Fatigue: VW's Single-Point-of-Failure Ethics', IEEE Security \& Privacy, Vol. 14, No. 1, pp 12-30.

[41] Trump, R. \& Newman, K. (2017). 'When do unethical brand perceptions spill over to competitors?' Marketing Letters, Vol. 28, No. 2, pp 219-230.

[42] VanSandt, C. (2016). 'The Volkswagen Scandal is Not an Ethical Issue', retrieved 13 March, 2018 from https://unibusinessethics.com/volkswagen-scandal-not-ethical-issue/. 15

[43] Valentinov, V. (2017). 'The Rawlsian Critique of Utilitarianism: A Luhmannian Interpretation', Journal of Business Ethics, Vol. 142, No. 1, pp 25-35.

[44] Warford, E. L. (2016). 'Ethics in the Classroom: The Volkswagen Diesel Scandal', retrieved 13 March, 2018 from https://peer.asee.org/ethics-in-the-classroom-the-volkswagen-diesel-scandal.pdf.

[45] Weiss, J. W. (2009). Business Ethics: A Stakeholder \& Issues Management Approach. Mason: South-Western Cengage Learning.

[46] Yang, X. (2006). 'Categorical imperatives, moral requirements, and moral motivation', Metaphilosophy, Vol. 37, No. 1, pp 112-129.

[47] Zhou, A. (2016). 'Analysis of the Volkswagen Scandal: Possible Solutions for Recovery', retrieved 15 January, 2020 from https://gps.ucsd.edu/_files/faculty/gourevitch/gourevitch_cs_zhou.pdf. 